\title{
TINJAUAN ATAS SISTEM PENGENDALIAN INTERNAL PENERIMAAN KAS PADA PERUSAHAAN DAERAH AIR MINUM (PDAM) KABUPATEN BUTON
}

\author{
Deki Pardana \\ Program Studi Akuntansi, Fakultas Ekonomi \\ Universitas Muhammadiyah Buton, Baubau, Indonesia \\ e-mail:dekiperdana81@gmail.com
}

\begin{abstract}
ABSTRAK
Penelitian ini bertujuan untuk mengetahui penerapan sistem pengendalian internal penerimaan kas pada Perusahaan Daerah Air Minum (PDAM) Kabupaten Buton. Dengan sampel data sistem pengendalian internal penerimaan kas tahun 2015 sampai dengan tahun 2016. Metode penelitian yang digunakan adalah analisis deksriptif kualitatif. Hasil penelitian menunjukkan bahwa penerapan sistem pengendalian internal penerimaan kas pada PDAM Kabupaten Buton sudah berjalan baik dilihat dari prosedur penerimaan kas yang ada pada perusahaan yaitu prosedur pencatatan pemasangan air, prosedur pembayaran dan penagihan, prosedur pembukuan, dan prosedur pelaporan.
\end{abstract}

Kata Kunci: Pengendalian Internal, Sistem Pengendalian Internal, Penerimaan Kas

\begin{abstract}
This study aims to determine the implementation of the internal control system for cash receipts at the Buton District Water Supply Company (PDAM). With a sample of internal control system data, cash receipts from 2015 to 2016. The research method used is qualitative descriptive analysis. The results showed that the implementation of the cash control internal control system in Buton District PDAM had gone well seen from the cash receipt procedures that existed in the company, namely procedures for recording water installations, payment and billing procedures, accounting procedures, and reporting procedures.
\end{abstract}

Keywords: Internal Control, Internal Control System, Cash Receipts

\section{PENDAHULUAN}

Tujuan utama dari perusahaan adalah memperoleh laba optimal serta mempertahankan kelangsungan hidup perusahaan tersebut. Dalam usaha mempertahankan kelangsungan hidup perusahaan serta memperoleh laba, perusahaan harus mengatur modalnya dengan baik [1]. Salah satu penanaman modal yang harus diatur adalah pada sektor modal kerja. Modal kerja harus dikelola dengan baik untuk mencapai hasil yang 
optimal dalam memperoleh laba serta mempertahankan kelangsungan hidup perusahaan [2].

Semakin berkembangnya perusahaan baik kegiatan maupun jumlah karyawan, pimpinan perusahaan tidak dapat lagi melaksanakan sendiri semua fungsinya, kondisi semacam ini menuntut pimpinan perusahaan untuk mendelegasikan sebagian tugas, wewenang serta tanggung jawab kepada beberapa bawahan yang dipimpinnya guna membantu pengelolaan perusahaan. Selain itu pimpinan perusahaan juga membutuhkan suatu alat untuk mengawasi jalannya tugas yang dipercayakan kepada bawahan serta untuk mengetahui kemajuan yang akan dicapai perusahaan. Untuk itu dibutuhkan suatu sistem yang lebih dikenal dengan sistem pengendalian internal.

Sistem pengendalian internal yang dirancang dengan baik terhadap struktur organisasi yang didalamnya terdapat pembagian tanggung jawab fungsional kepada unit-unit organisasi yang dibentuk untuk melaksanakan kegiatan-kegiatan pokok perusahaan, seperti pemisahan fungsi operasional, fungsi penyimpanan, dan fungsi pencatatan [3].Salah satu aktiva yang dimiliki perusahaan adalah kas.Kas perlu mendapat perhatian tersendiri, karena sifatnya yang sangat mudah dipindahtangankan dan tidak dapat dibuktikan kepemilikannya[4]. Dengan keadaan ini tentunya akan mendorong perusahaan untuk melakukan pengendalian internal terhadap penerimaan kas [5].

Suatu perusahaan menerapkan sistem pengendalian internal sebagai penunjang dalam menjalankan usahanya.Sistem tersebut disesuaikan dengan keadaan dan kondisi masing-masing perusahaan karena jenis dan bentuk perusahaan yang berbedabeda.Sistem pengendalian internal yaitu suatu sistem yang meliputi struktur organisasi, metode dan ukuran-ukuran yang dikoordinasikan untuk menjaga kekayaan organisasi, mengecek ketelitian dan keandalan data akuntansi, mendorong efisiensi dan mendorong dipatuhinya kebijakan manajemen [6].

Sistem pengendalian internal terhadap penerimaan kas yang meliputi strukturorganisasi, metode dan ukuran-ukuran yang dikoordinasikan perusahaan. Selain itu unsur-unsur pokok sistem pengendalian internal meliputi: organisasi yang memisahkan tanggung jawab dan wewenang secara tegas, sistem otorisasi dan prosedur pencatatan, praktik yang sehat, dan karyawan yang mutunya sesuai dengan tanggung jawab [7].Menurut tujuannya, sistem pengendalian internal tersebut dapat dibagi menjadi dua macam: pengendalian internal akuntansi (internal accounting control) dan pengendalian internal administratif (internal administrative control). 
Pengendalian internal akuntansi merupakan bagian dari sistem pengendalian internal meliputi struktur organisasi, metode dan ukuran-ukuran yang dikoordinasikan terutama untuk menjaga kekayaan organisasi dan mengecek ketelitian dan keandalan data akuntansi.Pengendalian internal administratif, meliputi struktur organisasi, metode dan ukuran-ukuran yang dikoordinasikan terutama untuk mendorong efisiensi dan dipatuhinya kebijakan manajemen [6].

Sistem pengendalian internal padaPerusahaan Daerah Air Minum (PDAM) dilaksanakan untuk menghindari terjadinya kecurangan pada penerimaan kas dan juga untuk mengetahui apakah sistem manajemen telah dilaksanakan dengan baik atau tidak. Pada dasarnya PDAM Kabupaten Buton telah memiliki uraian tugas yang baik namun menurut satuan pengawasan internal pada waktu pelaksanaannya, pemisahan tugas dan wewenang masih tidak sesuai dengan apa yang telah ditetapkan.

Perusahaan Daerah Air Minum merupakan Badan Usaha Milik Daerah (BUMD) yang berbentuk Perum dan bergerak dalam bidang pengelolaan air minum dan air kotor.Aktivitas yang dilakukan oleh PDAM salah satunya adalah menyediakan dan menyalurkan air yang cukup kepada pelanggannya. Untuk dapat melaksanakan pelayanan pelanggan yang optimal dibutuhkan modal kerja yang cukup memadai untuk membiayai operasionalnya.Salah satu komponen modal kerja yang rentan terhadap kecurangan ialah kas.Bentuk kecurangan yang dapat timbul dari lemahnya pengendalian internal kas ialah munculnya piutang tak tertagih yang begitu besar[8].Untuk itusistem pengendalian internal penerimaan kas harus secara memadai dilaksanakan sesuai dengan prosedur yang telah ditetapkan.Dari uraian di atas maka fokus penelitian ini ialah meninjaupenerapan sistem pengendalian internal penerimaan kas pada PDAMKabupaten Buton.

\section{METODE PENELITIAN}

Menurut mengemukakanbahwa populasi adalah keseluruhan subjek penelitian [9]. Populasi dalam penelitian ini adalah data-data sistem pengendalian internal penerimaan kas pada PDAM Kabupaten Buton.Sampel adalah sebagian atau mewakili populasi yang diteliti [9].Sampel dalam penelitian ini adalah data-data sistem pengendalian internal penerimaan kas tahun 2015 sampai dengan tahun 2016.

Jenis data yang digunakan dalam penelitian ialah data kuantitatif dan data kualitatif [10].Data kuantitatif, yaitu data yang dinyatakan dalam bentuk angkaangka.Dalam penelitian ini yang menjadi data kuatitatif yaitu berupa laporan tentang 
data dari sistem pengendalian internal pada PDAM Kabupaten Buton.Data kualitatif, yaitu data yang dinyatakan dalam bentuk kata-kata, diperoleh dari survei lapangan atau berupa opini.Dalam penelitian ini yang merupakan data kualitatif ialahinformasi atau penjelasan dari pimpinan atau karyawan tentang sistem pengendalian internal penerimaan kas pada PDAM Kabupaten Buton.

Sumber datayang digunakan dalam penelitian ini ialah data primer dan data sekunder. Menurut [9] data primer merupakan data dan informasi penelitian yang berhubungan langsung dengan penelitian dimana data diperoleh dari sumber internal dan wawancara dengan pihak yang terkait yangberhubungan dengan sistem pengendalian internal penerimaan kas pada PDAM Kabupaten Buton.Data sekunder merupakan sumber data yang diperoleh peneliti secara tidak langsung data tersebut meliputi buku, jurnal, literatul yang berhubungan dengan permasalahan yang ada [9].

Metode yang digunakan pada saat pengumpulan data diantaranya:(1) observasiatas sistem pengendalian internal penerimaan kas yang telah ada dari segi pengumpulan data dan sistem informasi akuntansi yang digunakan; (2) wawancara dilakukan dengan beberapa karyawan yang bertanggung jawab pada bagian tertentu yang menjadi sumber informasi; dan (3) dokumentasiyaitu mengumpulkan bahanbahan yang tertulis berupa data yang diperoleh dari PDAM Kabupaten Buton.

Metode analisis yang digunakan dalam penelitian ini adalah metode analisis deskriptif kualitatif. Metode analisis deksriptif kualitatif merupakan suatu prosedur penelitian yang menggunakan data deskriptif berupa kata-kata tertulis atau lisan dari orang-orang dan pelaku yang dapat diamati dan data tidak disajikan dalam bentuk angka-angka akan tetapi disajikan dalam bentuk kata-kata atau kalimat [9].

\section{HASIL DAN PEMBAHASAN}

\section{a. Hasil Penelitian}

Berdasarkan penelitian yang telah dilakukan di PDAM Kabupaten Buton, hal-hal yang peneliti dapatkan antara lain, sebagai berikut.

\section{Penerapan Sistem Pengendalian Internal Penerimaan Kas pada PDAM Kabupaten Buton.}

Dari hasil wawancara dengan ibu Mirawati, S.E Kepala Administrasi Bagian Umum yang dilakukan di Kantor PDAM Kabupaten Buton, tanggal 12 September 2017 menyatakan bahwa: 
"PDAM Kabupaten Buton dalam menerapkan sistem pengendalian internal penerimaan kas menggunakan sistem akuntansi penerimaan kas yang kami gunakan yaitu, bagaimana prosedur pencatatan, prosedur penagihan pembayaran, prosedur pembukuan, dan prosedur pelaporan.Dimana mempermudah kami untuk menerapkan sistem akuntansi penerimaan kas dengan baik".

\section{a. Prosedur Pencatatan Biaya Pemakaian Air pada PDAM}

1) Mencatat hasil pembacaan meteran pada langganan dalam kartu meter langganan dan daftar stand meter langganan, kemudian membuat daftar rekening ditagihkan rangkap 2 berdasarkan daftar stand meter langganan (DSML) dari pembaca meter dan dibuatkan laporan tagihan rekening dari seluruh pelanggan yang diperoleh dari petugas pembaca meter.

2) Prosedur Pencatatan di PDAM

Catatan akuntansi yang digunakan dalam sistem akuntansi penerimaan kas dari penjualan air adalah sebagai berikut:

a) Jurnal Penerimaan Kas (JPK)

Catatan ini berfungsi untuk mencatat pengakuan atas penerimaan rekening air, pada saat pelanggan melakukan pembayaran melalui Laporan Pelunasan Pelanggan (LPP).

b) Buku Pembantu Piutang Langganan (BPPL)

Dalam transaksi penjualan air, catatan ini berfungsi untuk mencatat piutang pelanggan air.Tiap pelanggan dicatat dalam 1 BPPL.

c) Daftar Saldo Piutang Langganan (DSPL)

Catatan ini berfungsi untuk mengetahui saldo piutang langganan tiap akhir bulan.

\section{b. Prosedur Penagihan dan Pembayaran pada PDAM}

1) Bagian kasir menerima Daftar Rekening Ditagihkan (DRD) Air lembar kedua dari bagian pengelola data digunakan untuk data pembuatan rekening dan diarsipkan.

2) Setelah selesai memasukkan data bagian kasir memulai pembayaran dengan menerima contoh rekening dari pelanggan.

3) Berdasarkan contoh rekening dari pelanggan bagian kasir memproses data pelanggan kemudian mencetak rekening rangkap 2.

4) Bagian kasir menerima pembayaran dari pelanggan dan menyerahkan rekening lembar ke 1 kepada pelanggan setelah di cap lunas. 
5) Berdasarkan rekening lembar ke 2, bagian kasir membuat Laporan Pelunasan Pelanggan (LPP) rangkap 2, Laporan Penerimaan Harian (LPH), Laporan Harian Kas (LHK) dan Bukti Kas Masuk (BMK) masing-masing rangkap 2 dan Setor Bank (SB) rangkap 2 (lalu diserahkan ke Bank dengan menyetor kas dari piutang yang kemudian diotorisasi oleh direktur Umum dan Kepala Bagian Keuangan, lalu didistribusikan sebagai berikut:

a) Laporan pelunasan pelanggan (LPP), Laporan pelunasan harian (LPH), laporan harian kas (LHK), dan bukti masuk kas (BMK) lembar ke 1 untuk bagian pembukuan.

b) Laporan pelunasan pelanggan (LPP), Laporan pelunasan harian (LPH), laporan harian kas (LHK), dan bukti masuk kas (BMK) lembar ke 2 untuk arsip bagian pengelola kas dan penagihan urut tanggal.

c) Setor bank (SB) lembar ke 1 untuk arsip Bank,.

d) Setor bank (SB) lembar ke 2 untuk bagian penagihan dan pembayaran (kasir).

\section{c. Prosedur Pembukuan di PDAM}

1) Bagian pembukuan menerima rekening lembar ke 2, Laporan Pelunasan Pelanggan (LPP), Laporan Pelanggan Harian (LPH), Laporan Harian Kas (LHK), dan Bukti Kas Masuk (BKM) lembar ke 1 dari bagian pengelola penagihan dan pembayaran.

2) Bagian pembukuan membandingkan rekening lembar ke 2, Laporan Pelunasan Pelanggan (LPP), Laporan Pelunasan Harian (LPH), Laporan Harian Kas (LHK) dan Bukti Masuk Kas (BMK) lembar ke 1, yang lalu digunakan sebagai dasar pencatatan jurnal penerimaan kas.

3) Bagian pembukuan mengarsipkan rekening lembar ke 2, Laporan Pelunasan Pelanggan (LPP), Laporan Pelunasan Harian (LPH), Laporan Harian Kas (LHK) dan Bukti Masuk Kas (BMK) lembar ke 1, yang lalu digunakan sebagai dasar pencatatan jurnal penerimaan kas.

\section{d. Prosedur Pelaporan di PDAM}

Bagian pelaporan setelah melakukan pembukuan dibuatlah jurnal secara manual yaitu jurnal rekening, jurnal penerimaan kas, jurnal bayar kas, jurnal pemakaian bahan instalasi kimia digublik, dari jurnal ini kemudian diinput ke program, 
program langsung buku besar, dibuatlah Neraca, Laporan laba rugi, Laporan ekuitas dan Laporan Arus Kas

\section{b. Pembahasan}

Dalam pembahasan penelitian ini penulis akan menghubungkan antara penerapan sistem pengendalian internal penerimaan kas yang ada di PDAM dengan sistem akuntansi penerimaan kas yang ada di teori.

\section{Fungsi yang Terkait dalam Sistem Akuntansi Penerimaan Kas pada PDAM}

Fungsi yang terkait dalam sistem akuntansi penerimaan kas PDAM Kabupaten Buton yaitu bagian pembaca meteran, bagian pengelola data, bagian kas dan penagihan (kasir), bagian pembukuan, bagian keuangan, dan bagian direktur umum. Sedangkan perbedaan pada teori berdasarkan fungsi yang terkait yaitu fungsi penjualan, fungsi gudang, dan fungsi pengiriman.

Dalam sistem akuntansi penerimaan kas PDAM Kabupaten Buton bagian yang terkait yaitu bagian pembaca meteran berfungsi untuk melakukan pembacaan meteran pada langganan lalu mencatat hasilnya dalam kartu meter langganan dan daftar stand meter langganan. Bagian pengelola data membuat daftar rekening ditagihkan rangkap 2 berdasarkan daftar stand meter langganan dari pembaca meter.Bagian kas dan penagihan (kasir) berfungsi menerima uang dari hasil tagihan penjualan ari dari pelanggan.Bagian pembukuan berfungsi untuk mencatat transaksi penjualan air dalam jurnal rekening dimana saat menerima kas dari pendapatan penjualan air maka fungsi ini mencatat dalam jurnal penerimaan kas.Bagian keuangan berfungsi mengevaluasi dan menganalisis perhitungan pelaksanaan anggaran perusahaan serta mengusulkan bahan penyusun, perubahan dan perhitungan anggaran pendapatan dan belanja perusahaan.Bagian direktur umum berfungsi menyusun dan menyampaikan laporan berkala seluruh kegiatan PDAM termasuk Neraca dan perhitungan Laba/Rugi kepada Bupati melalui Dewan Pengawas.

\section{Dokumen yang Digunakan dalam Sistem Akuntansi Penerimaan Kas pada PDAM}

Dokumen yang digunakan dalam sistem akuntansi penerimaan kas pada PDAM Kabupaten Buton yaitu rekening, kartu meter langganan, daftar stand meter langganan, daftar rekening ditagihkan, laporan pelunasan pelanggan, bukti masuk 
kas dan laporan harian kas.Sedangkan perbedaan pada teori berdasarkan dokumen yang terkait yaitu fungsi penjualan tunai, pita register kas, credit card sales slip, bill of lading, faktur penjualan, rekap harga pokok penjualan.

Dalam sistem akuntansi penerimaan kas pada PDAM Kabupaten Buton dokumen yang digunakan yaitu rekening dimana dokumen ini dicetak oleh bagian kasir sebagai pengakuan pendapatan air. Kartu meter langganan digunakan untuk mencatat pemakaian air pelanggan tiap bulannya. Daftar stand meter langganan digunakan untuk mencatat pemakaian air pelanggan menurut penggolongannya.Daftar rekening ditagihkan dibuat oleh pengelola data yang berupa laporan tagihan rekening dari seluruh pelanggan yang diperoleh dari petugas pembaca meter.Laporan pelunasan pelanggan dibuat oleh bagian kasir sebagai rekap dari penerimaan harian kas. Laporan harian kas dibuat oleh kasir setiap akhir jam kerja yang berupa hasil laporan pencatatan nominal transaksi penerimaan kas dari penjualan air selama satu hari kerja. Laporan penerimaan harian dibuat oleh kasir setiap akhir jam kerja yang berupa laporan rincian laporan harian kas yang dibuat rangkap 4 lembar dan berfungsi untuk mencatat semua penerimaan dari kas tertentu. Setor bank dibuat oleh fungsi kas sebagai bukti penyetoran kas yang diterima dari piutang ke bank dan digunakan sebagai dasar pencatatan transaksi penerimaan kas dari piutang ke dalam jurnal penerimaan kas.

\section{Catatan Akuntansi yang Digunakan dalam Sistem Akuntansi Penerimaan Kas pada PDAM}

Catatan yang digunakan dalam sistem akuntansi penerimaan kas pada PDAM Kabupaten Buton yaitu jurnal penerimaan kas, jurnal rekening, buku pembantu piutang langganan, dan daftar saldo piutang langganan Sedangkan yang ada pada teori berdasarkan catatan akuntansi yang digunakan yaitu jurnal penjualan, jurnal penerimaan kas, jurnal umum, kartu persediaan, dan kartu gudang.

Dimana dalam sistem akuntansi penerimaan kas pada PDAM catatan yang digunakan yaitu Jurnal penerimaan kas dimana catatan ini berfungsi untuk mencatat pengakuan atas penerimaan rekening air, pada saat pelanggan melakukan pembayaran melalui laporan pelunasan pelanggan.Jurnal rekening catatan ini berfungsi untuk mencatat transaksi penjualan air berdasarkan daftar rekening ditagihkan. Buku pembantu piutang langganan dalam transaksi penjualan air, catatan ini berfungsi untuk mencatat piutang pelanggan air dan non air dimana 
setiap pelanggan dicatat dalam 1 buku pembantu piutang langganan. Daftar saldo piutang langganan dimana catatan ini berfungsi untuk mengetahui saldo piutang langganan tiap akhir bulan.

\section{Jaringan Prosedur yang Membentuk dalam Sistem Akuntansi Penerimaan Kas pada PDAM}

Jaringan prosedur yang terbentuk dalam sistem akuntansi penerimaan kas PDAM Kabupaten Buton yaitu prosedur pembaca meter, prosedur pengelola data elektronik, dan prosedur kas dan penagihan, prosedur pembukuan. Sedangkan yang ada pada teori prosedur order penjualan, prosedur penerimaan kas, prosedur penyerahan barang, prosedur pencatatan, prosedur penyetoran kas ke bank, prosedur pencatatan penerimaan kas, prosedur pencatatan harga pokok penjualan.

Sistem akuntansi penerimaan kas PDAM Kabupaten Buton bagian jaringan prosedur yang digunakan yaitu prosedur pembaca meter dimana bagian pembacaan meter melakukan pembacaan meter tiap langganan dengan menggunakan alat PDT, kemudian memasukan angka meter ke kartu meter pelanggan. Prosedur pengelola data elektronik bagian pengelola data menerima file daftar stand meter langganan dari pembaca meter dan berdasarkan daftar stand meter langganan lalu membuat daftar rekening ditagihkan.

\section{KESIMPULAN}

Sesuai dengan hasil penelitian dan pembahasan maka dapat disimpulkan bahwa, perusahaan telah menerapkan sistem pengendalian internal dengan baik dalam prosedur penerimaan kas yaitu dari awal mula pemasangan meteran air, mencatat hasilnya dalam kartu meter langganan kemudian mengelola data dan mencatat transaksi penjualan air, membuat daftar rekening rangkap 2 untuk melakukan pembayaran dan penagihan yang disetor di bank, kemudian dibukukan dan dilaporkan.

\section{SARAN}

Saran yang dapat diberikan kepada PDAM Kabupaten Buton antara lain, sebagai berikut. Untuk melindungi harta kekayaan perusahaan dari pencurian, penggelapan dan persekongkolan antara karyawan dengan pihak ketiga maka perlu diterapkan sistem pengendalian internal yang baik. Untuk meningkatkan sistem pengendalian 
internal terhadap penerimaan kas, perludiadakan koreksi dari setiap pembayaran rekening air bersih oleh pelanggan.Untuk menghindari adanya penyalahgunaan pada sistem pengendalian internal penerimaan kas pada PDAM Kabupaten Buton sebaiknya pada bagian administrasi yang terkait lebih meningkatkan ketelitan, baik itu cara menghitung, mencatat kegiatan transaksi, dan menyimpan dokumen-dokumen atau slip setoran pembayaran pelanggan, agar terhindar dari kehilangan data dan juga supaya apabila ada kesalahan dapat dicari dengan mudah dan cepat.

\section{DAFTAR PUSTAKA}

[1] Suwardjono. 2005. Teori Akuntansi: Perekayasaan Pelaporan Keuangan. Yogyakarta: BPFE.

[2] Astuti, Dewi. 2002. Manajemen Keuangan Perusahaan. Jakarta: Ghalia Indonesia.

[3] Madri. 2011. Sistem Informasi Akuntansi. Bogor: Ghalia Indonesia

[4] Manullang. 2005. Sistem Pengawasan Internal. Jakarta: Salemba Empat.

[5] Bodnar, George H. dan Hopwood, William S. Diterjemahkan oleh Amir Abadi Yusuf dan Andi M. Tambunan, 2008. Sistem informasi Akuntansi. Jakarta: Salemba Empat.

[6] Mulyadi. 2014. Sistem AkuntansiEdisi Ketiga. Jakarta: Salemba Empat.

[7] Romney, Steinbart, 2012. Sistem Informasi AkuntansiEdisi Pertama. Jakarta: Salemba Empat.

[8] ACFE Indonesia Chapter \#111. Survei Fraud Indonesia.Association of Certified Fraud Examiner.

[9] Arikunto, 2006.Prosedur Penelitian Suatu Pendekatan Praktek Edisi Tiga Belas. Jakarta: PT. Rineka Cipta.

[10]Sugiyono,2007. Metodologi Penelitian Pendidikan Pendekatan Kuantitatif, kualitatif, dan $R \& D$. Bandung: ALFABETA 